\title{
Editorial
}

\section{Assédio Sexual e Moral no Trabalho}

\author{
Volume 16, Número 1, 2018
}

DOI: http://dx.doi.org/10.21714/1679-18272018v16n1.pI-II

Prezados Leitor@s,

A primeira edição de 2018 apresenta um conjunto de artigos que trazem um debate contemporâneo para o campo das organizações. São textos que abordam de forma específica, temas relacionados a educação e gestão educacional, gênero e assédio moral e sexual, comprometimento e entrincheiramento organizacional, consumo e trabalho, e socialização profissional. Apesar de todos os temas serem relevantes para a discussão na sociedade, destacamos a relevância de se discutir a questão do assédio moral e sexual no trabalho.

Em 2017, o Datafolha publicou uma pesquisa mostrando que 42\% das mulheres já vivenciaram o problema de serem assediadas sexualmente. As mais jovens são um pouco mais assediadas, pois esse percentual aumenta quando separadas as mulheres de 16-24 anos de idade. Considerando o local que geralmente ocorre o assédio sexual, o instituto revelou que $29 \%$ dos casos ocorrem na rua, $22 \%$ no transporte público, $15 \%$ no local de trabalho, $10 \%$ na escola ou faculdade e $6 \%$ em casa. Note-se que o percentual de ocorrência no ambiente de trabalho é relativamente elevado, o que deve ser levado em conta nas organizações.

A Comissão Para Igualdade no Trabalho e Emprego conceitua assédio sexual como "todo o comportamento indesejado de caráter sexual, sob forma verbal, não verbal ou física, com o objetivo ou o efeito de perturbar ou constranger a pessoa, afetar a sua dignidade, ou de lhe criar um ambiente intimidativo, hostil, degradante, humilhante ou desestabilizador". Apesar da clareza conceitual, há quem justifique ações dessa natureza como 'brincadeirinhas'. No entanto, tais atos geram dor e pesar por parte das que são assediadas. $\mathrm{O}$ fato é que o caso é grave e nem sempre as mulheres relatam o que sofrem. Com isso, convidamos os leitores e leitoras a refletirem mais sobre o tema, além de discutí-lo no trabalho e em casa.

Em relação aos artigos desta edição, o primeiro, intitulado "Brazil, Canada And China: A CrossCompare Study Of Its Educational Indicators" de Danilo de Melo Costa, analisou de forma comparativa os indicadores educacionais do Brasil, Canadá e China. Em seguida, na mesma temática, Leonardo Flach, Luísa Karam de Mattos avaliaram a relação entre os gastos realizados pelos estados brasileiros com Educação. Esse artigo tem como título "The Wellbeing Effect Of Education: Uma Análise Da Relação Entre Gastos Em Educação e os Resultados Sociais No Brasil".

Entrando no contexto do assédio, o artigo "A Influência Do Gênero Feminino Sobre A Ocorrência De Assédio Moral: Um Estudo Em Uma Rede De Postos De Combustível Na Cidade De Maringá" elaborado por Camilla Ariane Ajita Picironi, Cleiciele Albuquerque Augusto, procuram compreender a influência do gênero sobre as ocorrências de assédio moral, concluindo que a mulher ainda é discriminada em ambientes masculinizados. No quarto artigo intitulado "Percepções De Tutores Sobre O Assédio Sexual Sofrido Por Jovens Trabalhadores Nas Organizações", Alice de Freitas Oleto, José Vitor Palhares, Kely César Martins de Paiva e Letícia Rocha Guimarães, analisam como são 
http://www.revista.ufpe.br/gestaoorg

percebidas situações de assédio sexual vivenciadas por jovens trabalhadores sob a perspectiva dos profissionais da Associação Alfa que os assistem e contribuem para sua inclusão no mundo do trabalho. Os autores perceberam que os jovens que sofreram assédio sexual são predominantemente do gênero feminino e que a situação vivida traz consequências de natureza pessoal e profissional.

O quinto artigo "Comprometimento e Entrincheiramento Organizacionais: Uma Análise Comparativa com duas Instituições de Ensino Superior" de Rogério Castro Destêrro e Silva, Gean Carlos Tomazzoni e Vânia Medianeira Flores Costa, comparam a percepção dos técnico-administrativos em educação de duas instituições de ensino superior acerca do estabelecimento dos vínculos de comprometimento e entrincheiramento com as suas organizações. Já o sexto artigo intitulado "Comprometimento e Entrincheiramento Organizacional: Possíveis Correlações" foi desenvolvido por Jaqueline Cavalcante Milhome e Diva Ester Okazaki Rowe. As autoras verificaram o grau de correlação entre os referidos construtos, uma vez que dizem respeito à diferentes (não opostas) naturezas de ligação do trabalhador com a organização e coexistem no trabalhador.

O sétimo artigo intitulado como "Trabalho e Consumo: Proposta de Discussão acerca das Definições sobre o Processo de Co-criação" de Rosana Córdova Guimarães, apresenta uma discussão inicial, de natureza teórica, sobre as diferentes nomenclaturas que emergem no campo do marketing, marketing crítico e estudos organizacionais acerca do processo de co-criação. O último artigo desta edição, intitulado "Socialização Profissional: Aspectos da Formação Acadêmica em Secretariado Executivo" de Emiliano Sousa Pontes, Sandra Maria dos Santos, Augusto Cézar de Aquino Cabral, Cibele Barsalini Martins, Tereza Cristina Batista de Lima e Daniela Giareta Durante, analisa como ocorre o aprendizado dos conhecimentos, habilidades, normas e valores da profissão de secretário executivo na fase acadêmica do processo de socialização profissional.

Para encerrar esta edição, apresentamos a resenha "Prisão e Redenção: Fragmentos Estoicos para Pensar a Crítica Organizacional" de Ricardo Lebbos Favoreto e Arnaldo José França Mazzei Nogueira.

Navegarem nessa edição procurando extrair o que há de melhor em cada trabalho publicado.

Visite-nos sempre: http://www.revista.ufpe.br/gestaoorg/index.php/gestao/index

Saudações,

Francisco Vicente Sales Melo, Dr.

Editor-Chefe

Taciana de Barros Jerônimo, Dra.

Editora-Associada

Gestão: 2015-2018 